\title{
The Transcriptional Network in the Arabidopsis Circadian Clock System
}

\author{
Norihito Nakamichi ${ }^{1,2}$ \\ 1 Institute of Transformative Bio-Molecules, Nagoya University, Furo-cho, Chikusa, Nagoya 464-8602, Japan; \\ nnakamichi@itbm.nagoya-u.ac.jp \\ 2 Division of Biological Science, Graduate School of Science, Nagoya University, Furo-cho, Chikusa, \\ Nagoya 464-8602, Japan
}

Received: 24 September 2020; Accepted: 28 October 2020; Published: 29 October 2020

\begin{abstract}
The circadian clock is the biological timekeeping system that governs the approximately 24-h rhythms of genetic, metabolic, physiological and behavioral processes in most organisms. This oscillation allows organisms to anticipate and adapt to day-night changes in the environment. Molecular studies have indicated that a transcription-translation feedback loop (TTFL), consisting of transcriptional repressors and activators, is essential for clock function in Arabidopsis thaliana (Arabidopsis). Omics studies using next-generation sequencers have further revealed that transcription factors in the TTFL directly regulate key genes implicated in clock-output pathways. In this review, the target genes of the Arabidopsis clock-associated transcription factors are summarized. The Arabidopsis clock transcriptional network is partly conserved among angiosperms. In addition, the clock-dependent transcriptional network structure is discussed in the context of plant behaviors for adapting to day-night cycles.
\end{abstract}

Keywords: circadian clock; plant development; arabidopsis; transcriptional network; transcription factors

\section{Introduction}

Circadian regulation of biological processes is thought to be crucial for prediction and adaptation to day-night cycles. Many metabolic, physiological and behavioral processes are under the control of the circadian clock in plants [1,2]. Leaf movement has been recognized for a long time as a marker for circadian rhythms [3]. The circadian movement of legume leaves is driven by a circadian change in turgor pressure. Although Arabidopsis thaliana (Arabidopsis) also shows circadian cotyledon and leaf movement, the movement is driven by differential growth of the adaxial and abaxial sides of leaves, not by turgor pressure as in the case of legumes [3,4]. Arabidopsis also has additional rhythmic movements that occur during hypocotyl elongation and flowering stem elongation [3]. The speed of circumnutation of the flowering stem is also controlled by the circadian clock [5], as is stomatal opening and closure [6] and the optimal timing for defense responses [7,8]. Important for plant metabolism, the pace of starch breakdown during the night is controlled by the circadian clock $[9,10]$. These phenomena coordinate to give fitness (or an adaptive advantage) to plants during $24 \mathrm{~h}$ day-night cycles [11-13]. Field experiments further indicate that the clock is crucial for plant size, branching, flowering time and fitness in Arabidopsis [14,15].

Transcriptome analyses of Arabidopsis grown under diel and circadian conditions revealed that 6 to $26 \%$ of all genes are expressed cyclically, depending on the conditions of the experiment [16-18]. Meta-analysis of these transcriptome analyses showed that expression of about $90 \%$ of genes is cyclic at least in one diel or under circadian conditions [19]. By mining these transcriptome data, some biological processes under clock control were found. Expression of genes for the phenylpropanoid 
synthetic pathway is cyclic with a peak around dawn; this timing may enable Arabidopsis to produce phenylpropanoid-related secondary metabolites, some of which absorb light to protect cells like a sunscreen [16]. The expression of auxin-signaling genes is significantly circadian regulated. In addition, auxin sensitivity is higher during late night and lower in the daytime, showing that auxin sensitivity is gated by the clock [20]. Expression of dehydration-responsive element B1/C-repeat-binding factor (DREB1/CBF) genes, encoding key transcription factors for cold-stress responses, are circadian regulated [16]. Cold-stress-induced $D R E B 1 / C B F$ expression is gated by the clock, and induction of these genes is maximal in the morning and minimal in the evening [16,21]. The gate effect on DREB1/CBF is disrupted in clock mutants [21-23]. Collectively, transcriptome analyses have revealed the identity of genes and biological processes under clock control.

Many clock-associated genes encode proteins related to transcription, and these genes constitute a transcription-translation feedback loop (TTFL) for clock function [24,25]. CIRCADIAN CLOCK-ASSOCIATED 1 (CCA1) and LATE ELONGATED HYPOCOTYL (LHY) are the closest single Myb transcription factors expressed around dawn. CCA1 and LHY repress the transcription of clock-associated genes expressed from morning to evening. Target genes of CCA1 and LHY are EARLY FLOWERING 4 (ELF4), LUXARRHYTHMO (LUX), PSEUDO-RESPONSE REGULATOR 9 (PRR9), PRR7, PRR5, TIMING OF CAB EXPRESSION 1 (TOC1, also called PRR1), COLD-REGULATED GENE 27 (COR27), COR28 and GIGANTEA (GI) [26-30]. PRR9, PRR7 and PRR5 are transcription repressors and repress the transcription of CCA1, LHY, REVEILLE 8 (RVE8), NIGHT LIGHT-INDUCIBLE AND CLOCK-REGULATED 1 (LNK1), LNK2, LNK3, LNK4 and PRR genes expressed during earlier phases [31-33]. TOC1 also represses the target genes of other PRR [34,35]. In addition, TOC1 represses LUX, ELF4 and GI expression [35]. LUX, ELF4 and ELF3 form the protein complex known as the Evening Complex (EC) to repress PRR9, PRR7 and LUX [36-38]. LNK proteins interact with RVE8, and the LNK-RVE8 complex activates expression of PRR5 and TOC1 [39]. COR27 and COR28 repress PRR5 and TOC1 expression, although COR27 and COR28 have no DNA-binding activity in vitro. Thus, it is likely that COR27 and COR28 associate with TOC1 and PRR5 promoters by interacting with other transcription factors [40]. LIGHT-REGULATED 1 (LWD1) and LWD2 bind to TEOSINTE BRANCHED 1-CYCLOIDEA-PCF20 (TCP20) and TCP22 on the CCA1 promoter region and activate CCA1 transcription [41]. TCP21, known as CCA1-HIKING EXPEDITION (CHE), represses CCA1 [42]. This highly wired genetic network in which the expression of clock-associated genes is modulated by internal and external signals increases the variation in expression timing, a feature that may contribute to the ability of plants to adapt to environmental changes that originate from day-night cycles $[10,43-45]$.

\section{Transcriptional Networks under Clock Regulation}

\subsection{The Transcriptional Network of CCA1 and LHY}

Genetic studies have indicated that CCA1 and LHY are essential for the clock and influence output biological processes such as hypocotyl elongation, flowering time, cold-stress responses and photosynthesis [11,46-49]. A chromatin immunoprecipitation and deep sequencing (ChIPseq) study demonstrated that CCA1 associates with more than 1000 genomic loci in the Wassilewskija (WS) accession under constant light or diel conditions [27]. Another ChIPseq study indicated that CCA1 associates with about 400 loci in the Col-0 accession [26]. Gene numbers may be different in these two studies because the statistical values for finding peaks of short reads were different, and different materials were used (antibodies and Arabidopsis accessions). Comparison of these two studies revealed at least 254 loci of CCA1 occupancy in the Arabidopsis genome. The evening element (EE, AAATATCT) is enriched in the CCA1-immunoprecipitated DNA sequences [26,27], a result that is compatible with the finding that CCA1 binds to EE in vitro [16,50]. Other DNA sequences were also enriched in the CCA1-immunoprecipitated DNA, possibly suggesting that CCA1 associates with the target genes by constructing complexes with other transcription factors in vivo [26,27]. 
Many CCA1-bound genes are expressed in the evening (Figure 1). In the cca1 lhy double mutant, expression peaks of CCA1-target genes were advanced to morning phases [26,48]. Thus, CCA1 can determine the phase for expressing target genes [26]. The ChIP study also indicated that some CCA1-targets are not expressed in a diel or circadian rhythmic manner [27]. This result may suggest that there are genes whose transcription is regulated by CCA1 in specific conditions or in specific tissues or cells so that the effect of CCA1 is not clear under all growth conditions tested.

A study combining ChIPseq of LHY and transcriptome analysis identified the target genes of LHY [29]. Comparison between CCA1-binding loci and LHY-binding loci indicates that these two transcription factors have highly shared targets. However, there are ABA-related genes that are represented only in the LHY-target genes. Expression of NINE-CIS-EPOXYCAROTENOID DIOXYGENASE 3, encoding a rate-liming enzyme for abscisic acid (ABA) biosynthesis, was strongly reduced in transgenic plants overexpressing $L H Y$. Other genes for ABA-signaling components were altered in lhy loss-of-function and $L H Y$ over-expressing constructs. ABA sensitivity is also changed in these lines, showing ABA signaling control by LHY [29].

\subsection{The Transcriptional Network of LNK1 and RVE8}

Given that $\operatorname{lnk} 1 \ln k 2$ double mutants and rve8 rev6 rev4 triple mutants had long periods and altered clock-output processes, these genes are necessary for clock function [51-55]. A recent study indicates that RVE8 binds to LNK proteins, and this complex bound to the PRR5 and TOC1 promoters recruits the basal transcriptional machinery to induce PRR5 and TOC1 expression [39]. Genome-wide gene expression analysis indicated that $L N K 1$ and $L N K 2$ activate genes whose expression occurs in the afternoon [52]. These gene sets include FLAVIN-BINDING, KELCH REPEAT and F BOX 1 (FKF1), a key regulator of flowering time [56,57], suggesting that $L N K$ genes control flowering through $F K F 1$ expression (Figure 1). Transcriptome analysis using transgenic plants expressing chemically induced RVE8 identified the primary target genes of RVE8 [51]. RVE8-target genes are expressed in the evening and include genes involved in responses such as external stimuli, defense and temperature changes [51].

\subsection{The Transcriptional Network of PRR9, PRR7, PRR5 and TOC1}

PRR9, PRR7, PRR5 and TOC1 (PRR1) proteins are sequentially expressed from early morning to midnight [58-60] and are crucial for clock function. Altered phenotypes of clock-output processes such as flowering time, hypocotyl elongation, cold-stress responses, drought-stress responses, greening, and metabolite alteration in $\mathrm{prr}$ and toc1 mutants indicated the importance of PRR and TOC1 for these biological processes [22,61-69]. Transcriptome analyses of prr mutants and transgenic lines and ChIPseq studies of PRR9, PRR7 and PRR5 proteins indicated that the three PRR proteins share target genes [31-33] (Figure 1). The target genes are significantly enriched in genes encoding transcription factors. The three PRR proteins directly repress expression of CYCLING DOF FACTOR (CDF) genes that encode transcription factors capable of repressing the florigen gene FT and CONSTANS (CO), a transcriptional activator of FT [70]. PRR9, PRR7, PRR5 and TOC1 repress PHYTOCHROME INTERACTING FACTOR 4 (PIF4) and PIF5, two genes that encode transcription factors capable of inducing hypocotyl growth in the dark [71,72]. The three PRR proteins repress DREB1/CBF genes that encode transcription factors for cold-stress responses [73]. Except for the DREB1 gene, PRR-target genes tend to have expression patterns with peaks at dawn and the early morning. The gate effect of cold stress-dependent DREB1 induction was highly attenuated in the prr9 prr7 prr5 triple mutants [22]. Expression of these PRR-target genes was upregulated in the prr9 prr7 prr5 mutants compared to wild type, suggesting that these PRR proteins repress the target genes [31]. PRR9, PRR7 and PRR5 possess a transcriptional repression motif [59] that recruits histone deacetyl transferases to the PRR-targets CCA1 and LHY [74].

Recombinant CCT domains of PRR proteins, except PRR3, bind to a T1ME DNA sequence (TGTG or CACA) of the CCA1 promoter in vitro [34]. A recent study further demonstrated that the CCT domain, NF-YB, and NF-YC form a complex, and the complex binds to CCACA elements 
in vitro [75]. ChIPseq studies showed that the G-box (CACGTG)-like DNA sequences were enriched in the PRR-immunoprecipitated fractions [31-33,35], though it is possible that the PRR proteins associate with G-box like elements through protein-protein interaction due to cross-linking during the ChIP procedure. Not all PRR-bound DNA contains CCACA- or G-box-like sequences, suggesting that PRRs may associate with DNA by binding to other transcription factors in vivo [31,33]. Indeed, PRR proteins bind to some transcription factors. PRR, PIF and CO are known to interact with PRRs [76-81]. PRRs can modulate the stability or activity of these proteins. Given that PRRs regulate transcription of $P R R$, PIF and CO directly or indirectly [31,82], it is possible to propose that PRRs regulate these transcription factors at the transcriptional and post-translational steps. Regulation at multiple steps may allow these transcription factor activities to be under strict and precise control by the clock.

\subsection{The Transcriptional Network of ELF3, ELF4 and LUX}

The EC, an essential protein complex in the clock, consists of ELF3, ELF4 and LUX [38]. The elf3, elf4 and lux mutants impair clock output processes such as flowering time regulation and hypocotyl elongation [36,37,83-89]. ChIPseq of ELF3, ELF4 and LUX confirms that these proteins share target genes [90] (Figure 1). Enriched DNA sequences found in and bound by LUX are the LBS and the G-box; the former is bound by LUX in vitro [37], whereas the latter is bound by b-HLH and b-ZIP transcription factors. LUX may bind to such G-box-binding transcription factors on G-boxes. Most of the EC-target genes are upregulated in the elf3, elf4 and $l u x$ mutants, suggesting a repressive role of the EC [90]. The EC interacts with the SWI2/SNF2-RELATED (SWR1) complex to regulate deposition of H2A.Z-nucleosomes at the EC-targets [91].

An intriguing feature of EC function is its functioning at cooler conditions, which explains part of the clock's entrainment mechanism that uses temperature changes as environmental time cues. Genome-wide gene expression changes resulting from the elf3 mutation compared to the wild-type at $22{ }^{\circ} \mathrm{C}$ is correlated to that at $27^{\circ} \mathrm{C}$ compared to $22{ }^{\circ} \mathrm{C}$ in the wild-type [90]. The EC-target genes, such as PRR7, PRR9, LUX and PIF4, are induced by a warm-temperature shift during the early night; this induction is diminished in the mutants whose EC components are impaired [92,93]. In vitro experiments further show that the EC binds to the LBS with high affinity under cooler conditions [94]. In addition to the temperature-dependent response at the molecular level, the EC regulates temperature responses beyond organs, given that ELF4 translated in shoot tissues moves to roots in cooler temperatures and sets the clock in root tissues [95].

The EC targets two key light signaling genes, PIF4 and PIF5 [38]. ChIPseq revealed that the EC targets additional light-signaling genes whose expression is rapidly induced by light [93]. The EC also targets genes implicated in the heat- and cold-stress responses, $D R E B 1 / C B F$ and $D R E B 2$. Other prominent biological processes of the EC-targets include growth-related processes. For example, BANQUO1 (BNQ1)/ PACLOBUTAZOL1 RESISTANCE1 (PRE1) and BNQ2/PRE2, implicated in cell elongation and flowering time, are directly regulated by the EC [90]. The EC targets ARABIDOPSIS RESPONSE REGULATOR6 (ARR6), ARR7, CYTOKININ RESPONSE FACTOR (CRF4) and CRF5 genes implicated in cytokinin responses. Collectively, the EC directs key genes involved in photosynthesis, temperature stress and growth [90].

\subsection{The Transcriptional Network of GI}

Given that null mutants of GI alter the period length and amplitude, GI is required for clock function [96]. Despite its essential role, the molecular function or biochemical activity of GI remained unknown for a long time. Recent biochemical and molecular biology studies have suggested that GI possesses multifunctional biochemical activities. GI possesses protein chaperone activity and helps ZEITLUPE (ZTL) mature into an active form [97]. Since ZTL is the ubiquitin E3-ligase for TOC1 and PRR5 [60,98,99], GI affects the levels of these proteins [97]. Given that the $g i$ and $z t l$ mutants have shorter and longer periods, respectively, GI seems to control period length through ZTL-independent pathways. Recently, a chromatin immunoprecipitation assay showed that GI protein associates with the 
CCA1 promoter [100]. GI does not have a typical DNA-binding domain, suggesting that other proteins bridge between GI and the CCA1 promoter. In addition, GI binds to PIF transcription factors and modulates the stability and activity of PIFs [100]. PIFs bind to the CCA1 promoter in the light-input pathway and affect CCA1 transcription [100]. Thus, GI controls CCA1 transcription in multiple ways, including controlling the stability of TOC1 and PRR5, two transcriptional repressors of CCA1.

The ChIPseq study indicated that genomic loci bound by GI and PIF3 overlap significantly, showing close interaction between these proteins [100] (Figure 1). At the highest GI-binding signal loci (top 10\%), PIF3-binding signals were greater in the gi null mutants, suggesting that GI inhibits PIF3 binding to DNA. Common targets of PIF3 and GI are enriched in genes related to the circadian clock, the response to water deprivation, the response to chitin, the ethylene-activated signaling pathway and transcription. Although the impact of GI-PIF interaction on the overall physiology of plants still needs to be determined, the interaction is crucial for light input to the clock and for controlling hypocotyl elongation through regulating CCA1 and PIF3-LIKE1 genes [100].

GI is known to regulate not only the clock and hypocotyl elongation but also a wide range of physiological processes [101]. Photoperiodic flowering time regulation is one GI-controlled developmental process in which GI functions in at least three pathways (Figure 1). First, GI binds to and modulates the activity of FKF1, a ubiquitin E3 ligase that targets the degradation of flowering repressor transcription factors, CDF proteins that inhibit the transcription of $F T$ and CO genes [56,57]. Simultaneously, GI associates with FT promoter regions [102]. GI also upregulates miR172 that targets transcriptional repressors of FT [103]. GI interacts with SPINDLY protein, an O-linked beta-N-acetylglucosamine transferase that modulates flowering time, thus confirming an additional pathway in which GI controls flowering [104].

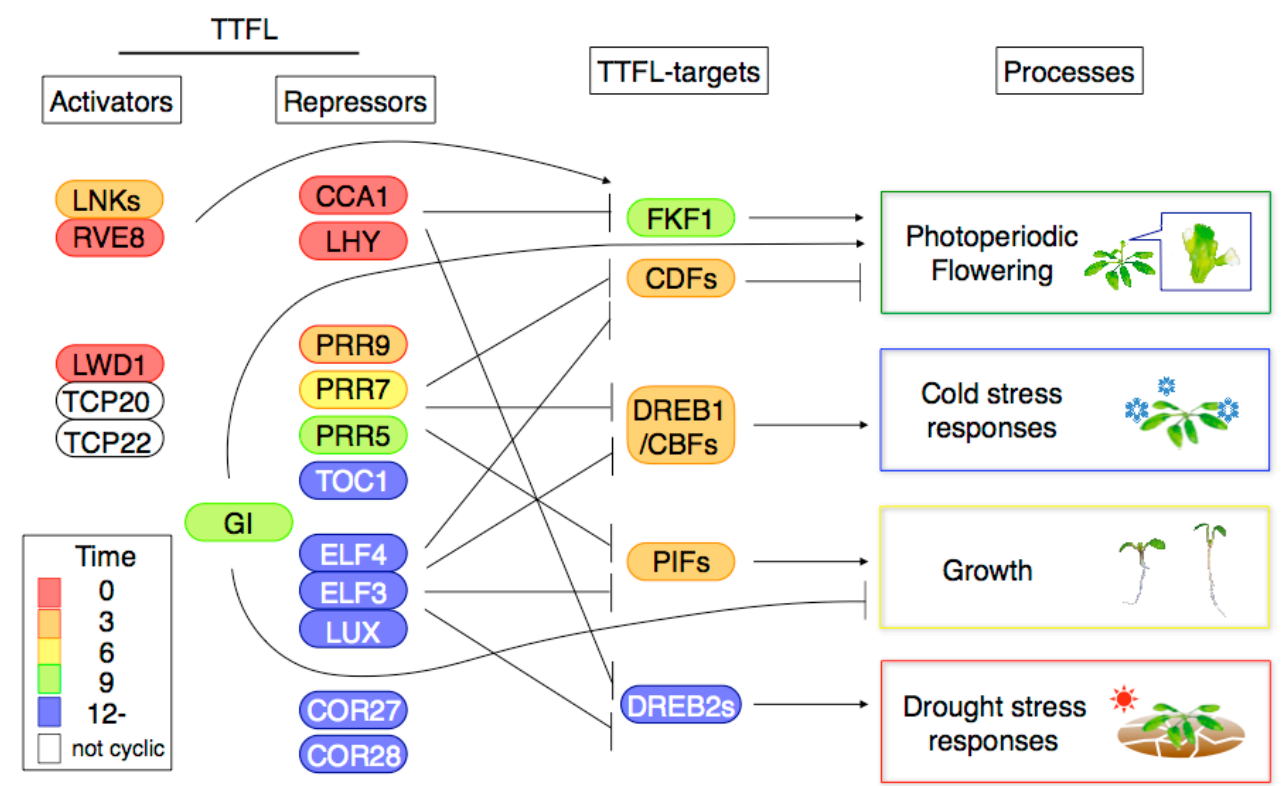

Figure 1. A model of the transcriptional network of the Arabidopsis circadian clock. The clock transcription-translation feedback loop (TTFL) regulates biological processes through regulating key genes (TTFL-targets). Interactions within the clock TTFL are not shown. 'Time' is the peak time for mRNA expression under $12 \mathrm{~h}$ light/12 h dark conditions in DIURNAL [105]. Other TTFL-targets are detailed in the text.

\subsection{Possible Interactions among Clock Transcription Factors for Regulating Gene Expression}

There are some common target genes that are regulated by different classes of clock-transcription factors (Figure 1). PIF4, PIF5, three DREB1/CBF genes, CDF2, CDF3, RVE1, RVE7, B-BOX DOMAIN PROTEIN 24 (BBX24) and EARLY LIGHT-INDUCABLE PROTEIN 1 (ELIP1) genes are targeted by PRR5 and the EC. DREB2C, DREB2H, RVE7, GI, PRR7, PRR9 and LUX genes are targeted by CCA1 and the 
EC. RVE7, PRR7 and PRR9 are targets of PRR5 and CCA1. The combinatorial binding of PRR5 and CCA1 may cause shifts in the timing of gene expression of the target genes [26]. How different classes of clock-associated transcription factors, including RVE, LNK and TCP proteins, interact to regulate target output genes is an intriguing and yet to be determined question.

\section{An Evolutionary View of Clock-Dependent Transcriptional Networks in Plants}

\subsection{The Transcriptional Network under Clock Control in Angiosperms}

Details about the molecular components of the plant clock have been examined thoroughly in Arabidopsis; however, transcriptome analyses of other plants have indicated that the clock transcriptional network is partly conserved among angiosperms [106]. Comparable diel transcriptome analyses of Arabidopsis, Populus and rice showed that the phases of expression peaks of many circadian clock-associated genes, such as CCA1/LHY, GI, LUX, PRR and TOC1, are highly similar among these plants [106]. Orthologous genes of the clock-output pathways are expressed at a similar time-of-day among these plants [106]. Furthermore, cis-regulatory elements found in the Arabidopsis clock transcriptional network, such as morning element (ME), the G-box for morning-phased expression, EE, GATA for evening expression and the protein box (PBX)/ the telo-box (TBX)/ the starch box (SBX) for midnight expression, are conserved in rice and Populus $[19,106]$. Some homologs of the Arabidopsis PRR5-target genes in rice and Populus are repressed when PRR homologs are expressed, suggesting that the Arabidopsis PRR5 transcriptional network is partly conserved in rice and Populus [107].

Output biological processes under clock control are divergent among species, organs, tissues and cells. Recently, the expression of an outward anion channel gene was reported to peak around dawn in flexor motor cells, but not in extensor motor cells, in the pulvinus of Samanea saman, a mimosoid tree, suggesting that anion channel-dependent cell shrinkage of flexor cells during the daytime is crucial for leaf movement [108]. Solar tracking of sunflower stems is driven by opposing growth rhythms on the east and west sides of the stems [109]. Sunflower LHY-and TOC1-homolog genes are expressed at a specific time-of-day similar to those in Arabidopsis. The expression of these genes is similar in both sides of sunflower stems; however, two homologs of genes involved in phototropism are expressed differently on the opposite sides, suggesting the molecular basis underpinning solar tracking [109]. In Arabidopsis, the clock in epidermal cells controls PIF4 expression to coordinate thermo-responsive growth $[110,111]$. Photoperiodic flowering is regulated by the vascular clock in Arabidopsis [112]. These studies clearly indicate the importance of tissue or cell-specific clock-output gene regulation, which is also indicated by time-course transcriptome analyses of distinct organs or tissues in Arabidopsis [111-113]. In addition, clock parameters such as the period and amplitude are different among cells in whole plants [114,115], though there are couplings of clocks among cells $[113,116]$. In the future, single-cell level transcriptome analyses will identify how cell-type-specific clock output is controlled.

In rice, OsCCA1 and OsTOC1 control tillering and panicle development by regulating genes for strigolactone signaling [75]. OsGI is essential for robust diel transcriptome rhythms in the field [117]. Recent molecular-genetic studies have suggested that flowering times of some crops were optimized by naturally or artificially occurring mutations in the orthologues of Arabidopsis clock-associated genes [118-120]. This evidence strongly suggests that the core clock network described in Arabidopsis is conserved in angiosperms, but divergent means of regulating clock outputs are consequences of distinct strategies for adapting to the environment.

\subsection{The Transcriptional Network under Clock Control in the Plant Lineage}

Comparison of genomes and diel transcriptome data for organisms spanning the Archaeplastida provides some evolutionary insight into diel gene expression in the plant lineage [121,122]. These studies indicate that homologs of the clock-associated genes in Arabidopsis are conserved among tracheophytes (from ferns to flowering plants). Homologs of CCA1/LHY, RVE and LUX are conserved 
in Archaeplastida, whereas other clock-associated genes are not. A GI homolog is not found in the bryophyte Physcomitrella patens [121], but GI and FKF1 homologs are crucial for day-length-dependent growth-phase transition in another bryophyte, Marchantia polymorpha [123]. PRR, TOC1, ELF3, ELF4 and GI homologs are not found in Cyanophora paradoxa (early-diverging alga, glaucophyte) or in Porphyridium purpureum (rhodophyte). PRR and TOC1 are found in two species of chlorophyte, Chlamydomonas reinhardtii and Ostreococcus tauri $[121,124]$. Ostreococcus CCA1 binds to EE on the Ostreococcus TOC1 promoter, and this binding is required for evening-phased gene expression [124], showing a similar relationship between CCA1 and TOC1 in Arabidopsis. Two LUX homologs are required for Chlamydomonas clock function [125], though homologs of ELF4 and ELF3 are absent in this alga. A LUX homolog (ROC75) is expressed during the day, and ROC75 protein directly represses a homolog of CCA1/LHY. These results indicate that the TTFL for clock function differs between Chlamydomonas and Arabidopsis [125].

\section{Conclusions}

Thanks to intrinsic genomic approaches such as RNAseq and ChIPseq using Arabidopsis seedlings, the target genes of CCA1/LHY, LNKs, RVE8, PRRs/TOC1, the EC and GI have been characterized. The network architecture provides time-of-day information from the clock TTFL to output pathways. Comparative transcriptome analyses indicate that the clock TTFL is conserved in many land plants; however, clock output gene expression is thought to be organ-, tissue- or cell-specific in order to control the output properly to adjust to environmental fluctuations coming from day-night or seasonal changes. This illustration of the transcriptional network under clock control at the organ or tissue level in diverse plants provides deeper insight into the ability of plants to adapt to $24 \mathrm{~h}$ and seasonal cycles.

Funding: This research was funded by Grants-in-Aid for Scientific Research, grant numbers 18H02136, $20 \mathrm{H} 05411$ and 20K21272 and the Nagase Science Technology Foundation.

Conflicts of Interest: The author declares no conflict of interest. The funders had no role in the writing of the manuscript.

\section{References}

1. McClung, C.R. The Plant Circadian Oscillator. Biology 2019, 8, 14. [CrossRef]

2. Barak, S.; Tobin, E.M.; Andronis, C.; Sugano, S.; Green, R.M. All in good time: The Arabidopsis circadian clock. Trends Plant Sci. 2000, 5, 517-522. [CrossRef]

3. McClung, C.R. Plant circadian rhythms. Plant Cell 2006, 18, 792-803. [CrossRef]

4. Kim, H.Y.; Cote, G.G.; Crain, R.C. Potassium Channels in Samanea saman Protoplasts Controlled by Phytochrome and the Biological Clock. Science 1993, 260, 960-962. [CrossRef]

5. Niinuma, K.; Someya, N.; Kimura, M.; Yamaguchi, I.; Hamamoto, H. Circadian rhythm of circumnutation in inflorescence stems of Arabidopsis. Plant Cell Physiol. 2005, 46, 1423-1427. [CrossRef]

6. Salome, P.A.; Michael, T.P.; Kearns, E.V.; Fett-Neto, A.G.; Sharrock, R.A.; McClung, C.R. The out of phase 1 mutant defines a role for PHYB in circadian phase control in Arabidopsis. Plant Physiol. 2002, 129, 1674-1685. [CrossRef]

7. Wang, W.; Barnaby, J.Y.; Tada, Y.; Li, H.; Tor, M.; Caldelari, D.; Lee, D.U.; Fu, X.D.; Dong, X. Timing of plant immune responses by a central circadian regulator. Nature 2011, 470, 110-114. [CrossRef]

8. Goodspeed, D.; Chehab, E.W.; Min-Venditti, A.; Braam, J.; Covington, M.F. Arabidopsis synchronizes jasmonate-mediated defense with insect circadian behavior. Proc. Natl. Acad. Sci. USA 2012, 109, 4674-4677. [CrossRef]

9. Graf, A.; Schlereth, A.; Stitt, M.; Smith, A.M. Circadian control of carbohydrate availability for growth in Arabidopsis plants at night. Proc. Natl. Acad. Sci. USA 2010, 107, 9458-9463. [CrossRef]

10. Webb, A.A.R.; Seki, M.; Satake, A.; Caldana, C. Continuous dynamic adjustment of the plant circadian oscillator. Nat. Commun. 2019, 10, 550. [CrossRef] 
11. Dodd, A.N.; Salathia, N.; Hall, A.; Kevei, E.; Toth, R.; Nagy, F.; Hibberd, J.M.; Millar, A.J.; Webb, A.A. Plant circadian clocks increase photosynthesis, growth, survival, and competitive advantage. Science 2005, 309, 630-633. [CrossRef]

12. Green, R.M.; Tingay, S.; Wang, Z.Y.; Tobin, E.M. Circadian rhythms confer a higher level of fitness to Arabidopsis plants. Plant Physiol. 2002, 129, 576-584. [CrossRef]

13. Yerushalmi, S.; Yakir, E.; Green, R.M. Circadian clocks and adaptation in Arabidopsis. Mol. Ecol. 2011, 20, 1155-1165. [CrossRef]

14. Rubin, M.J.; Brock, M.T.; Davis, A.M.; German, Z.M.; Knapp, M.; Welch, S.M.; Harmer, S.L.; Maloof, J.N.; Davis, S.J.; Weinig, C. Circadian rhythms vary over the growing season and correlate with fitness components. Mol. Ecol. 2017, 26, 5528-5540. [CrossRef]

15. Rubin, M.J.; Brock, M.T.; Baker, R.L.; Wilcox, S.; Anderson, K.; Davis, S.J.; Weinig, C. Circadian rhythms are associated with shoot architecture in natural settings. New Phytol. 2018, 219, 246-258. [CrossRef]

16. Harmer, S.L.; Hogenesch, J.B.; Straume, M.; Chang, H.S.; Han, B.; Zhu, T.; Wang, X.; Kreps, J.A.; Kay, S.A. Orchestrated transcription of key pathways in Arabidopsis by the circadian clock. Science 2000, 290, 2110-2113. [CrossRef]

17. Edwards, K.D.; Anderson, P.E.; Hall, A.; Salathia, N.S.; Locke, J.C.; Lynn, J.R.; Straume, M.; Smith, J.Q.; Millar, A.J. FLOWERING LOCUS C mediates natural variation in the high-temperature response of the Arabidopsis circadian clock. Plant Cell 2006, 18, 639-650. [CrossRef]

18. Blasing, O.E.; Gibon, Y.; Gunther, M.; Hohne, M.; Morcuende, R.; Osuna, D.; Thimm, O.; Usadel, B.; Scheible, W.R.; Stitt, M. Sugars and circadian regulation make major contributions to the global regulation of diurnal gene expression in Arabidopsis. Plant Cell 2005, 17, 3257-3281. [CrossRef]

19. Michael, T.P.; Mockler, T.C.; Breton, G.; McEntee, C.; Byer, A.; Trout, J.D.; Hazen, S.P.; Shen, R.; Priest, H.D.; Sullivan, C.M.; et al. Network discovery pipeline elucidates conserved time-of-day-specific cis-regulatory modules. PLoS Genet. 2008, 4, e14. [CrossRef]

20. Covington, M.F.; Harmer, S.L. The circadian clock regulates auxin signaling and responses in Arabidopsis. PLoS Biol. 2007, 5, e222. [CrossRef]

21. Fowler, S.G.; Cook, D.; Thomashow, M.F. Low temperature induction of Arabidopsis CBF1, 2, and 3 is gated by the circadian clock. Plant Physiol. 2005, 137, 961-968. [CrossRef]

22. Nakamichi, N.; Kusano, M.; Fukushima, A.; Kita, M.; Ito, S.; Yamashino, T.; Saito, K.; Sakakibara, H.; Mizuno, T. Transcript profiling of an Arabidopsis PSEUDO RESPONSE REGULATOR arrhythmic triple mutant reveals a role for the circadian clock in cold stress response. Plant Cell Physiol. 2009, 50, 447-462. [CrossRef]

23. Kidokoro, S.; Yoneda, K.; Takasaki, H.; Takahashi, F.; Shinozaki, K.; Yamaguchi-Shinozaki, K. Different Cold-Signaling Pathways Function in the Responses to Rapid and Gradual Decreases in Temperature. Plant Cell 2017, 29, 760-774. [CrossRef]

24. Nohales, M.A.; Kay, S.A. Molecular mechanisms at the core of the plant circadian oscillator. Nat. Struct. Mol. Biol. 2016, 23, 1061-1069. [CrossRef]

25. Greenham, K.; McClung, C.R. Integrating circadian dynamics with physiological processes in plants. Nat. Rev. Genet. 2015, 16, 598-610. [CrossRef]

26. Kamioka, M.; Takao, S.; Suzuki, T.; Taki, K.; Higashiyama, T.; Kinoshita, T.; Nakamichi, N. Direct Repression of Evening Genes by CIRCADIAN CLOCK-ASSOCIATED1 in the Arabidopsis Circadian Clock. Plant Cell 2016, 28, 696-711. [CrossRef] [PubMed]

27. Nagel, D.H.; Doherty, C.J.; Pruneda-Paz, J.L.; Schmitz, R.J.; Ecker, J.R.; Kay, S.A. Genome-wide identification of CCA1 targets uncovers an expanded clock network in Arabidopsis. Proc. Natl. Acad. Sci. USA 2015, 112, E4802-E4810. [CrossRef] [PubMed]

28. Adams, S.; Manfield, I.; Stockley, P.; Carre, I.A. Revised Morning Loops of the Arabidopsis Circadian Clock Based on Analyses of Direct Regulatory Interactions. PLoS ONE 2015, 10, e0143943. [CrossRef] [PubMed]

29. Adams, S.; Grundy, J.; Veflingstad, S.R.; Dyer, N.P.; Hannah, M.A.; Ott, S.; Carre, I.A. Circadian control of abscisic acid biosynthesis and signalling pathways revealed by genome-wide analysis of LHY binding targets. New Phytol. 2018, 220, 893-907. [CrossRef]

30. Li, G.; Siddiqui, H.; Teng, Y.; Lin, R.; Wan, X.Y.; Li, J.; Lau, O.S.; Ouyang, X.; Dai, M.; Wan, J.; et al. Coordinated transcriptional regulation underlying the circadian clock in Arabidopsis. Nat. Cell Biol. 2011, 13, 616-622. [CrossRef] 
31. Nakamichi, N.; Kiba, T.; Kamioka, M.; Suzuki, T.; Yamashino, T.; Higashiyama, T.; Sakakibara, H.; Mizuno, T. Transcriptional repressor PRR5 directly regulates clock-output pathways. Proc. Natl. Acad. Sci. USA 2012, 109, 17123-17128. [CrossRef] [PubMed]

32. Liu, T.; Carlsson, J.; Takeuchi, T.; Newton, L.; Farre, E.M. Direct regulation of abiotic responses by the Arabidopsis circadian clock component PRR7. Plant J. 2013, 76, 101-114. [CrossRef] [PubMed]

33. Liu, T.; Newton, L.; Liu, M.J.; Shiu, S.H.; Farre, E.M. A G-box-like motif is necessary for transcriptional regulation by circadian pseudo-response regulators in Arabidopsis. Plant Physiol. 2016, 170, 528-539. [CrossRef] [PubMed]

34. Gendron, J.M.; Pruneda-Paz, J.L.; Doherty, C.J.; Gross, A.M.; Kang, S.E.; Kay, S.A. Arabidopsis circadian clock protein, TOC1, is a DNA-binding transcription factor. Proc. Natl. Acad. Sci. USA 2012, 109, 3167-3172. [CrossRef] [PubMed]

35. Huang, W.; Perez-Garcia, P.; Pokhilko, A.; Millar, A.J.; Antoshechkin, I.; Riechmann, J.L.; Mas, P. Mapping the core of the Arabidopsis circadian clock defines the network structure of the oscillator. Science 2012, 336, 75-79. [CrossRef]

36. Dixon, L.E.; Knox, K.; Kozma-Bognar, L.; Southern, M.M.; Pokhilko, A.; Millar, A.J. Temporal Repression of Core Circadian Genes Is Mediated through EARLY FLOWERING 3 in Arabidopsis. Curr. Biol. 2011, 21, 120-125. [CrossRef]

37. Helfer, A.; Nusinow, D.A.; Chow, B.Y.; Gehrke, A.R.; Bulyk, M.L.; Kay, S.A. LUX ARRHYTHMO Encodes a Nighttime Repressor of Circadian Gene Expression in the Arabidopsis Core Clock. Curr. Biol. 2011, 21, 126-133. [CrossRef]

38. Nusinow, D.A.; Helfer, A.; Hamilton, E.E.; King, J.J.; Imaizumi, T.; Schultz, T.F.; Farre, E.M.; Kay, S.A. The ELF4-ELF3-LUX complex links the circadian clock to diurnal control of hypocotyl growth. Nature 2011, 475, 398-402. [CrossRef]

39. Ma, Y.; Gil, S.; Grasser, K.D.; Mas, P. Targeted Recruitment of the Basal Transcriptional Machinery by LNK Clock Components Controls the Circadian Rhythms of Nascent RNAs in Arabidopsis. Plant Cell 2018, 30, 907-924. [CrossRef]

40. Li, X.; Ma, D.; Lu, S.X.; Hu, X.; Huang, R.; Liang, T.; Xu, T.; Tobin, E.M.; Liu, H. Blue Light- and Low Temperature-Regulated COR27 and COR28 Play Roles in the Arabidopsis Circadian Clock. Plant Cell 2016, 28, 2755-2769. [CrossRef]

41. Wu, J.F.; Tsai, H.L.; Joanito, I.; Wu, Y.C.; Chang, C.W.; Li, Y.H.; Wang, Y.; Hong, J.C.; Chu, J.W.; Hsu, C.P.; et al. LWD-TCP complex activates the morning gene CCA1 in Arabidopsis. Nat. Commun. 2016, 7, 13181. [CrossRef] [PubMed]

42. Pruneda-Paz, J.L.; Breton, G.; Para, A.; Kay, S.A. A functional genomics approach reveals CHE as a component of the Arabidopsis circadian clock. Science 2009, 323, 1481-1485. [CrossRef] [PubMed]

43. Flis, A.; Sulpice, R.; Seaton, D.D.; Ivakov, A.A.; Liput, M.; Abel, C.; Millar, A.J.; Stitt, M. Photoperiod-dependent changes in the phase of core clock transcripts and global transcriptional outputs at dawn and dusk in Arabidopsis. Plant Cell Environ. 2016, 39, 1955-1981. [CrossRef] [PubMed]

44. Millar, A.J. The Intracellular Dynamics of Circadian Clocks Reach for the Light of Ecology and Evolution. Annu. Rev. Plant Biol. 2016, 67, 595-618. [CrossRef]

45. Harmer, S.L. The circadian system in higher plants. Annu. Rev. Plant Biol. 2009, 60, 357-377. [CrossRef]

46. Wang, Z.Y.; Tobin, E.M. Constitutive expression of the CIRCADIAN CLOCK ASSOCIATED 1 (CCA1) gene disrupts circadian rhythms and suppresses its own expression. Cell 1998, 93, 1207-1217. [CrossRef]

47. Schaffer, R.; Ramsay, N.; Samach, A.; Corden, S.; Putterill, J.; Carre, I.A.; Coupland, G. The late elongated hypocotyl mutation of Arabidopsis disrupts circadian rhythms and the photoperiodic control of flowering. Cell 1998, 93, 1219-1229. [CrossRef]

48. Mizoguchi, T.; Wheatley, K.; Hanzawa, Y.; Wright, L.; Mizoguchi, M.; Song, H.R.; Carre, I.A.; Coupland, G. LHY and CCA1 are partially redundant genes required to maintain circadian rhythms in Arabidopsis. Dev. Cell 2002, 2, 629-641. [CrossRef]

49. Lai, A.G.; Doherty, C.J.; Mueller-Roeber, B.; Kay, S.A.; Schippers, J.H.; Dijkwel, P.P. CIRCADIAN CLOCK-ASSOCIATED 1 regulates ROS homeostasis and oxidative stress responses. Proc. Natl. Acad. Sci. USA 2012, 109, 17129-17134. [CrossRef]

50. Alabadi, D.; Oyama, T.; Yanovsky, M.J.; Harmon, F.G.; Mas, P.; Kay, S.A. Reciprocal regulation between TOC1 and LHY/CCA1 within the Arabidopsis circadian clock. Science 2001, 293, 880-883. [CrossRef] 
51. Hsu, P.Y.; Devisetty, U.K.; Harmer, S.L. Accurate timekeeping is controlled by a cycling activator in Arabidopsis. Elife 2013, 2, e00473. [CrossRef] [PubMed]

52. Rugnone, M.L.; Faigon Soverna, A.; Sanchez, S.E.; Schlaen, R.G.; Hernando, C.E.; Seymour, D.K.; Mancini, E.; Chernomoretz, A.; Weigel, D.; Mas, P.; et al. LNK genes integrate light and clock signaling networks at the core of the Arabidopsis oscillator. Proc. Natl. Acad. Sci. USA 2013, 110, 12120-12125. [CrossRef]

53. Xie, Q.; Wang, P.; Liu, X.; Yuan, L.; Wang, L.; Zhang, C.; Li, Y.; Xing, H.; Zhi, L.; Yue, Z.; et al. LNK1 and LNK2 are transcriptional coactivators in the Arabidopsis circadian oscillator. Plant Cell 2014, 26, 2843-2857. [CrossRef]

54. De Leone, M.J.; Hernando, C.E.; Romanowski, A.; Garcia-Hourquet, M.; Careno, D.; Casal, J.; Rugnone, M.; Mora-Garcia, S.; Yanovsky, M.J. The LNK Gene Family: At the Crossroad between Light Signaling and the Circadian Clock. Genes 2019, 10, 2. [CrossRef] [PubMed]

55. Shalit-Kaneh, A.; Kumimoto, R.W.; Filkov, V.; Harmer, S.L. Multiple feedback loops of the Arabidopsis circadian clock provide rhythmic robustness across environmental conditions. Proc. Natl. Acad. Sci. USA 2018, 115, 7147-7152. [CrossRef] [PubMed]

56. Sawa, M.; Nusinow, D.A.; Kay, S.A.; Imaizumi, T. FKF1 and GIGANTEA complex formation is required for day-length measurement in Arabidopsis. Science 2007, 318, 261-265. [CrossRef]

57. Imaizumi, T.; Schultz, T.F.; Harmon, F.G.; Ho, L.A.; Kay, S.A. FKF1 F-box protein mediates cyclic degradation of a repressor of CONSTANS in Arabidopsis. Science 2005, 309, 293-297. [CrossRef]

58. Matsushika, A.; Makino, S.; Kojima, M.; Mizuno, T. Circadian waves of expression of the APRR1/TOC1 family of pseudo-response regulators in Arabidopsis thaliana: Insight into the plant circadian clock. Plant Cell Physiol. 2000, 41, 1002-1012. [CrossRef]

59. Nakamichi, N.; Kiba, T.; Henriques, R.; Mizuno, T.; Chua, N.H.; Sakakibara, H. PSEUDO-RESPONSE REGULATORS 9, 7, and 5 are transcriptional repressors in the Arabidopsis circadian clock. Plant Cell 2010, 22, 594-605. [CrossRef]

60. Mas, P.; Kim, W.Y.; Somers, D.E.; Kay, S.A. Targeted degradation of TOC1 by ZTL modulates circadian function in Arabidopsis thaliana. Nature 2003, 426, 567-570. [CrossRef]

61. Nakamichi, N.; Kita, M.; Ito, S.; Yamashino, T.; Mizuno, T. PSEUDO-RESPONSE REGULATORS, PRR9, PRR7 and PRR5, together play essential roles close to the circadian clock of Arabidopsis thaliana. Plant Cell Physiol. 2005, 46, 686-698. [CrossRef]

62. Yamamoto, Y.; Sato, E.; Shimizu, T.; Nakamich, N.; Sato, S.; Kato, T.; Tabata, S.; Nagatani, A.; Yamashino, T.; Mizuno, T. Comparative genetic studies on the APRR5 and APRR7 genes belonging to the APRR1/TOC1 quintet implicated in circadian rhythm, control of flowering time, and early photomorphogenesis. Plant Cell Physiol. 2003, 44, 1119-1130. [CrossRef] [PubMed]

63. Ito, S.; Niwa, Y.; Nakamichi, N.; Kawamura, H.; Yamashino, T.; Mizuno, T. Insight into missing genetic links between two evening-expressed pseudo-response regulator genes TOC1 and PRR5 in the circadian clock-controlled circuitry in Arabidopsis thaliana. Plant Cell Physiol. 2008, 49, 201-213. [CrossRef] [PubMed]

64. Kato, T.; Murakami, M.; Nakamura, Y.; Ito, S.; Nakamichi, N.; Yamashino, T.; Mizuno, T. Mutants of circadian-associated PRR genes display a novel and visible phenotype as to light responses during de-etiolation of Arabidopsis thaliana seedlings. Biosci. Biotechnol. Biochem. 2007, 71, 834-839. [CrossRef]

65. Fukushima, A.; Kusano, M.; Nakamichi, N.; Kobayashi, M.; Hayashi, N.; Sakakibara, H.; Mizuno, T.; Saito, K. Impact of clock-associated Arabidopsis pseudo-response regulators in metabolic coordination. Proc. Natl. Acad. Sci. USA 2009, 106, 7251-7256. [CrossRef] [PubMed]

66. Yamashino, T.; Ito, S.; Niwa, Y.; Kunihiro, A.; Nakamichi, N.; Mizuno, T. Involvement of Arabidopsis clock-associated pseudo-response regulators in diurnal oscillations of gene expression in the presence of environmental time cues. Plant Cell Physiol. 2008, 49, 1839-1850. [CrossRef] [PubMed]

67. Somers, D.E.; Webb, A.A.; Pearson, M.; Kay, S.A. The short-period mutant, toc1-1, alters circadian clock regulation of multiple outputs throughout development in Arabidopsis thaliana. Development 1998, 125, 485-494. [PubMed]

68. Yanovsky, M.J.; Kay, S.A. Molecular basis of seasonal time measurement in Arabidopsis. Nature 2002, 419, 308-312. [CrossRef]

69. Legnaioli, T.; Cuevas, J.; Mas, P. TOC1 functions as a molecular switch connecting the circadian clock with plant responses to drought. EMBO J. 2009, 28, 3745-3757. [CrossRef] 
70. Song, Y.H.; Smith, R.W.; To, B.J.; Millar, A.J.; Imaizumi, T. FKF1 conveys timing information for CONSTANS stabilization in photoperiodic flowering. Science 2012, 336, 1045-1049. [CrossRef]

71. Nozue, K.; Covington, M.F.; Duek, P.D.; Lorrain, S.; Fankhauser, C.; Harmer, S.L.; Maloof, J.N. Rhythmic growth explained by coincidence between internal and external cues. Nature 2007, 448, 358-361. [CrossRef] [PubMed]

72. Li, N.; Zhang, Y.; He, Y.; Wang, Y.; Wang, L. Pseudo Response Regulators Regulate Photoperiodic Hypocotyl Growth by Repressing PIF4/5 Transcription. Plant Physiol. 2020, 183, 686-699. [CrossRef] [PubMed]

73. Liu, Q.; Kasuga, M.; Sakuma, Y.; Abe, H.; Miura, S.; Yamaguchi-Shinozaki, K.; Shinozaki, K. Two transcription factors, DREB1 and DREB2, with an EREBP/AP2 DNA binding domain separate two cellular signal transduction pathways in drought- and low-temperature-responsive gene expression, respectively, in Arabidopsis. Plant Cell 1998, 10, 1391-1406. [CrossRef]

74. Wang, L.; Kim, J.; Somers, D.E. Transcriptional corepressor TOPLESS complexes with pseudoresponse regulator proteins and histone deacetylases to regulate circadian transcription. Proc. Natl. Acad. Sci. USA 2013, 110, 761-766. [CrossRef]

75. Wang, F.; Han, T.; Song, Q.; Ye, W.; Song, X.; Chu, J.; Li, J.; Chen, Z.J. Rice Circadian Clock Regulates Tiller Growth and Panicle Development Through Strigolactone Signaling and Sugar Sensing. Plant Cell 2020. [CrossRef] [PubMed]

76. Makino, S.; Matsushika, A.; Kojima, M.; Yamashino, T.; Mizuno, T. The APRR1/TOC1 quintet implicated in circadian rhythms of Arabidopsis thaliana: I. Characterization with APRR1-overexpressing plants. Plant Cell Physiol. 2002, 43, 58-69. [CrossRef]

77. Para, A.; Farre, E.M.; Imaizumi, T.; Pruneda-Paz, J.L.; Harmon, F.G.; Kay, S.A. PRR3 Is a vascular regulator of TOC1 stability in the Arabidopsis circadian clock. Plant Cell 2007, 19, 3462-3473. [CrossRef]

78. Fujiwara, S.; Wang, L.; Han, L.; Suh, S.S.; Salome, P.A.; McClung, C.R.; Somers, D.E. Post-translational regulation of the Arabidopsis circadian clock through selective proteolysis and phosphorylation of pseudo-response regulator proteins. J. Biol. Chem. 2008, 283, 23073-23083. [CrossRef]

79. Hayama, R.; Sarid-Krebs, L.; Richter, R.; Fernandez, V.; Jang, S.; Coupland, G. PSEUDO RESPONSE REGULATORs stabilize CONSTANS protein to promote flowering in response to day length. EMBO J. 2017, 36, 904-918. [CrossRef]

80. Martin, G.; Rovira, A.; Veciana, N.; Soy, J.; Toledo-Ortiz, G.; Gommers, C.M.M.; Boix, M.; Henriques, R.; Minguet, E.G.; Alabadi, D.; et al. Circadian Waves of Transcriptional Repression Shape PIF-Regulated Photoperiod-Responsive Growth in Arabidopsis. Curr. Biol. 2018, 28, 311-318. [CrossRef]

81. Zhang, Y.; Pfeiffer, A.; Tepperman, J.M.; Dalton-Roesler, J.; Leivar, P.; Grandio, E.G.; Quail, P.H. Central clock components modulate plant shade avoidance by directly repressing transcriptional activation activity of PIF proteins. Proc. Natl. Acad. Sci. USA 2020, 117, 3261-3269. [CrossRef]

82. Nakamichi, N.; Kita, M.; Niinuma, K.; Ito, S.; Yamashino, T.; Mizoguchi, T.; Mizuno, T. Arabidopsis clock-associated pseudo-response regulators PRR9, PRR7 and PRR5 coordinately and positively regulate flowering time through the canonical CONSTANS-dependent photoperiodic pathway. Plant Cell Physiol. 2007, 48, 822-832. [CrossRef] [PubMed]

83. Doyle, M.R.; Davis, S.J.; Bastow, R.M.; McWatters, H.G.; Kozma-Bognar, L.; Nagy, F.; Millar, A.J.; Amasino, R.M. The ELF4 gene controls circadian rhythms and flowering time in Arabidopsis thaliana. Nature 2002, 419, 74-77. [CrossRef]

84. Kolmos, E.; Nowak, M.; Werner, M.; Fischer, K.; Schwarz, G.; Mathews, S.; Schoof, H.; Nagy, F.; Bujnicki, J.M.; Davis, S.J. Integrating ELF4 into the circadian system through combined structural and functional studies. HFSP J. 2009, 3, 350-366. [CrossRef]

85. Zagotta, M.T.; Hicks, K.A.; Jacobs, C.I.; Young, J.C.; Hangarter, R.P.; Meeks-Wagner, D.R. The Arabidopsis ELF3 gene regulates vegetative photomorphogenesis and the photoperiodic induction of flowering. Plant J. 1996, 10, 691-702. [CrossRef] [PubMed]

86. Covington, M.F.; Panda, S.; Liu, X.L.; Strayer, C.A.; Wagner, D.R.; Kay, S.A. ELF3 modulates resetting of the circadian clock in Arabidopsis. Plant Cell 2001, 13, 1305-1315. [CrossRef]

87. Liu, X.L.; Covington, M.F.; Fankhauser, C.; Chory, J.; Wagner, D.R. ELF3 encodes a circadian clock-regulated nuclear protein that functions in an Arabidopsis PHYB signal transduction pathway. Plant Cell 2001, 13, 1293-1304. 
88. Hazen, S.P.; Schultz, T.F.; Pruneda-Paz, J.L.; Borevitz, J.O.; Ecker, J.R.; Kay, S.A. LUX ARRHYTHMO encodes a Myb domain protein essential for circadian rhythms. Proc. Natl. Acad. Sci. USA 2005, 102, 10387-10392. [CrossRef]

89. Onai, K.; Ishiura, M. PHYTOCLOCK 1 encoding a novel GARP protein essential for the Arabidopsis circadian clock. Genes Cells 2005, 10, 963-972. [CrossRef]

90. Ezer, D.; Jung, J.H.; Lan, H.; Biswas, S.; Gregoire, L.; Box, M.S.; Charoensawan, V.; Cortijo, S.; Lai, X.; Stockle, D.; et al. The evening complex coordinates environmental and endogenous signals in Arabidopsis. Nat. Plants 2017, 3, 17087. [CrossRef] [PubMed]

91. Tong, M.; Lee, K.; Ezer, D.; Cortijo, S.; Jung, J.; Charoensawan, V.; Box, M.S.; Jaeger, K.; Takahashi, N.; Mas, P.; et al. The Evening Complex establishes repressive chromatin domains via H2A.Z deposition. Plant Physiol. 2020, 182, 612-625. [CrossRef] [PubMed]

92. Mizuno, T.; Kitayama, M.; Oka, H.; Tsubouchi, M.; Takayama, C.; Nomoto, Y.; Yamashino, T. The EC night-time repressor plays a crucial role in modulating circadian clock transcriptional circuitry by conservatively double-checking both warm-night and night-time-light signals in a synergistic manner in Arabidopsis thaliana. Plant Cell Physiol. 2014, 55, 2139-2151. [CrossRef]

93. Thines, B.; Harmon, F.G. Ambient temperature response establishes ELF3 as a required component of the core Arabidopsis circadian clock. Proc. Natl. Acad. Sci. USA 2010, 107, 3257-3262. [CrossRef]

94. Silva, C.S.; Nayak, A.; Lai, X.; Hutin, S.; Hugouvieux, V.; Jung, J.H.; Lopez-Vidriero, I.; Franco-Zorrilla, J.M.; Panigrahi, K.C.S.; Nanao, M.H.; et al. Molecular mechanisms of Evening Complex activity in Arabidopsis. Proc. Natl. Acad. Sci. USA 2020, 117, 6901-6909. [CrossRef] [PubMed]

95. Chen, W.W.; Takahashi, N.; Hirata, Y.; Ronald, J.; Porco, S.; Davis, S.J.; Nusinow, D.A.; Kay, S.A.; Mas, P. A mobile ELF4 delivers circadian temperature information from shoots to roots. Nat. Plants 2020, 6, 416-426. [CrossRef] [PubMed]

96. Park, D.H.; Somers, D.E.; Kim, Y.S.; Choy, Y.H.; Lim, H.K.; Soh, M.S.; Kim, H.J.; Kay, S.A.; Nam, H.G. Control of circadian rhythms and photoperiodic flowering by the Arabidopsis GIGANTEA gene. Science 1999, 285, 1579-1582. [CrossRef]

97. Cha, J.Y.; Kim, J.; Kim, T.S.; Zeng, Q.; Wang, L.; Lee, S.Y.; Kim, W.Y.; Somers, D.E. GIGANTEA is a co-chaperone which facilitates maturation of ZEITLUPE in the Arabidopsis circadian clock. Nat. Commun. 2017, 8. [CrossRef]

98. Kiba, T.; Henriques, R.; Sakakibara, H.; Chua, N.H. Targeted degradation of PSEUDO-RESPONSE REGULATOR5 by an SCFZTL complex regulates clock function and photomorphogenesis in Arabidopsis thaliana. Plant Cell 2007, 19, 2516-2530. [CrossRef]

99. Kim, W.Y.; Fujiwara, S.; Suh, S.S.; Kim, J.; Kim, Y.; Han, L.; David, K.; Putterill, J.; Nam, H.G.; Somers, D.E. ZEITLUPE is a circadian photoreceptor stabilized by GIGANTEA in blue light. Nature 2007, 449, 356-360. [CrossRef]

100. Nohales, M.A.; Liu, W.; Duffy, T.; Nozue, K.; Sawa, M.; Pruneda-Paz, J.L.; Maloof, J.N.; Jacobsen, S.E.; Kay, S.A. Multi-level Modulation of Light Signaling by GIGANTEA Regulates Both the Output and Pace of the Circadian Clock. Dev. Cell 2019, 49, 840-851.e8. [CrossRef]

101. Mishra, P.; Panigrahi, K.C. GIGANTEA-an emerging story. Front. Plant Sci. 2015, 6. [CrossRef] [PubMed]

102. Sawa, M.; Kay, S.A. GIGANTEA directly activates Flowering Locus T in Arabidopsis thaliana. Proc. Natl. Acad. Sci. USA 2011, 108, 11698-11703. [CrossRef]

103. Jung, J.H.; Seo, Y.H.; Seo, P.J.; Reyes, J.L.; Yun, J.; Chua, N.H.; Park, C.M. The GIGANTEA-regulated microRNA172 mediates photoperiodic flowering independent of CONSTANS in Arabidopsis. Plant Cell 2007, 19, 2736-2748. [CrossRef]

104. Tseng, T.S.; Salome, P.A.; McClung, C.R.; Olszewski, N.E. SPINDLY and GIGANTEA interact and act in Arabidopsis thaliana pathways involved in light responses, flowering, and rhythms in cotyledon movements. Plant Cell 2004, 16, 1550-1563. [CrossRef]

105. Mockler, T.C.; Michael, T.P.; Priest, H.D.; Shen, R.; Sullivan, C.M.; Givan, S.A.; McEntee, C.; Kay, S.A.; Chory, J. The DIURNAL project: DIURNAL and circadian expression profiling, model-based pattern matching, and promoter analysis. Cold Spring Harb. Symp. Quant. Biol. 2007, 72, 353-363. [CrossRef] [PubMed]

106. Filichkin, S.A.; Breton, G.; Priest, H.D.; Dharmawardhana, P.; Jaiswal, P.; Fox, S.E.; Michael, T.P.; Chory, J.; Kay, S.A.; Mockler, T.C. Global Profiling of Rice and Poplar Transcriptomes Highlights Key Conserved Circadian-Controlled Pathways and cis-Regulatory Modules. PLoS ONE 2011, 6, e16907. [CrossRef] 
107. Toda, Y.; Kudo, T.; Kinoshita, T.; Nakamichi, N. Evolutionary Insight into the Clock-Associated PRR5 Transcriptional Network of Flowering Plants. Sci. Rep. 2019, 9. [CrossRef]

108. Oikawa, T.; Ishimaru, Y.; Munemasa, S.; Takeuchi, Y.; Washiyama, K.; Hamamoto, S.; Yoshikawa, N.; Mutara, Y.; Uozumi, N.; Ueda, M. Ion Channels Regulate Nyctinastic Leaf Opening in Samanea saman. Curr. Biol. 2018, 28, 2230-2238. [CrossRef]

109. Atamian, H.S.; Creux, N.M.; Brown, E.A.; Garner, A.G.; Blackman, B.K.; Harmer, S.L. Circadian regulation of sunflower heliotropism, floral orientation, and pollinator visits. Science 2016, 353, 587-590. [CrossRef]

110. Kim, S.; Hwang, G.; Kim, S.; Thi, T.N.; Kim, H.; Jeong, J.; Kim, J.; Kim, J.; Choi, G.; Oh, E. The epidermis coordinates thermoresponsive growth through the phyB-PIF4-auxin pathway. Nat. Commun. 2020, 11. [CrossRef]

111. Shimizu, H.; Katayama, K.; Koto, T.; Torii, K.; Araki, T.; Endo, M. Decentralized circadian clocks process thermal and photoperiodic cues in specific tissues. Nat. Plants 2015, 1, 15163. [CrossRef]

112. Endo, M.; Shimizu, H.; Nohales, M.A.; Araki, T.; Kay, S.A. Tissue-specific clocks in Arabidopsis show asymmetric coupling. Nature 2014, 515, 419-422. [CrossRef] [PubMed]

113. Takahashi, N.; Hirata, Y.; Aihara, K.; Mas, P. A hierarchical multi-oscillator network orchestrates the Arabidopsis circadian system. Cell 2015, 163, 148-159. [CrossRef] [PubMed]

114. Gould, P.D.; Domijan, M.; Greenwood, M.; Tokuda, I.T.; Rees, H.; Kozma-Bognar, L.; Hall, A.J.; Locke, J.C. Coordination of robust single cell rhythms in the Arabidopsis circadian clock via spatial waves of gene expression. Elife 2018, 7. [CrossRef]

115. Muranaka, T.; Oyama, T. Heterogeneity of cellular circadian clocks in intact plants and its correction under light-dark cycles. Sci. Adv. 2016, 2, e1600500. [CrossRef]

116. Fukuda, H.; Nakamichi, N.; Hisatsune, M.; Murase, H.; Mizuno, T. Synchronization of plant circadian oscillators with a phase delay effect of the vein network. Phys. Rev. Lett. 2007, 99, 098102. [CrossRef]

117. Izawa, T.; Mihara, M.; Suzuki, Y.; Gupta, M.; Itoh, H.; Nagano, A.J.; Motoyama, R.; Sawada, Y.; Yano, M.; Hirai, M.Y.; et al. Os-GIGANTEA Confers Robust Diurnal Rhythms on the Global Transcriptome of Rice in the Field. Plant Cell 2011, 23, 1741-1755. [CrossRef]

118. Nakamichi, N. Adaptation to the local environment by modifications of the photoperiod response in crops. Plant Cell Physiol. 2015, 56, 594-604. [CrossRef]

119. Bendix, C.; Marshall, C.M.; Harmon, F.G. Circadian Clock Genes Universally Control Key Agricultural Traits. Mol. Plant 2015, 8, 1135-1152. [CrossRef]

120. Li, M.W.; Liu, W.; Lam, H.M.; Gendron, J.M. Characterization of Two Growth Period QTLs Reveals Modification of PRR3 Genes During Soybean Domestication. Plant Cell Physiol. 2019, 60, 407-420. [CrossRef]

121. Ferrari, C.; Proost, S.; Janowski, M.; Becker, J.; Nikoloski, Z.; Bhattacharya, D.; Price, D.; Tohge, T.; Bar-Even, A.; Fernie, A.; et al. Kingdom-wide comparison reveals the evolution of diurnal gene expression in Archaeplastida. Nat. Commun. 2019, 10, 737. [CrossRef] [PubMed]

122. Linde, A.M.; Eklund, D.M.; Kubota, A.; Pederson, E.R.A.; Holm, K.; Gyllenstrand, N.; Nishihama, R.; Cronberg, N.; Muranaka, T.; Oyama, T.; et al. Early evolution of the land plant circadian clock. New Phytol. 2017, 216, 576-590. [CrossRef] [PubMed]

123. Kubota, A.; Kita, S.; Ishizaki, K.; Nishihama, R.; Yamato, K.T.; Kohchi, T. Co-option of a photoperiodic growth-phase transition system during land plant evolution. Nat. Commun. 2014, 5. [CrossRef]

124. Corellou, F.; Schwartz, C.; Motta, J.P.; Djouani-Tahri el, B.; Sanchez, F.; Bouget, F.Y. Clocks in the green lineage: Comparative functional analysis of the circadian architecture of the picoeukaryote ostreococcus. Plant Cell 2009, 21, 3436-3449. [CrossRef]

125. Matsuo, T.; Iida, T.; Ohmura, A.; Gururaj, M.; Kato, D.; Mutoh, R.; Ihara, K.; Ishiura, M. The role of ROC75 as a daytime component of the circadian oscillator in Chlamydomonas reinhardtii. Plos Genet. 2020, 16. [CrossRef]

Publisher's Note: MDPI stays neutral with regard to jurisdictional claims in published maps and institutional affiliations.

(C) 2020 by the author. Licensee MDPI, Basel, Switzerland. This article is an open access article distributed under the terms and conditions of the Creative Commons Attribution (CC BY) license (http://creativecommons.org/licenses/by/4.0/). 